\title{
Islam and Modernity
}




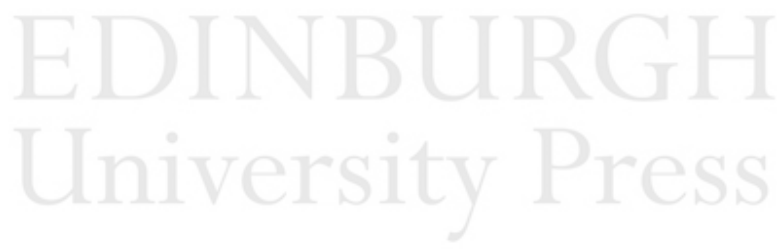

Not for distribution or resale. For personal use only. 


\title{
Islam and Modernity
}

Key Issues and Debates

\author{
Edited by Muhammad Khalid Masud, \\ Armando Salvatore and Martin van Bruinessen
}

Edinburgh University Press 
(C) in this edition Edinburgh University Press, 2009

(C) in the individual contributions is retained by the authors

Edinburgh University Press Ltd

22 George Square, Edinburgh

www.euppublishing.com

Typeset in 11/13pt Monotype Baskerville by

Servis Filmsetting Ltd, Stockport, Cheshire, and

printed and bound in Great Britain by

CPI Antony Rowe, Chippenham and Eastbourne

A CIP record for this book is available from the British Library

ISBN 9780748637928 (hardback)

ISBN 9780748637935 (paperback)

The right of the contributors to be identified as authors of this work has been asserted in accordance with the Copyright, Designs and Patents Act 1988. 